\title{
BÍBLIA E DESCOLONIZAÇÃO: LEITURAS DESDE UMA HERMENÊUTICA BÍBLICA NEGRA E FEMINISTA DE LIBERTAÇÃO
}

\author{
Maricel Mena-López* \\ Claudia Pilar de la Calle** \\ Loida Sardiñas Iglesias***
}

\begin{abstract}
RESUMO
Este artigo faz uma revisão histórica do processo de negação do aporte intelectual e acadêmico dos descendentes de africanos desde tempos memoráveis até o debate contemporâneo dos estudos culturais atuais resgatando, especialmente, $\mathrm{o}$ aporte das mulheres nos estudos do transfundo afro-asiático na Bíblia hebraica e cristã desde uma teologia negra e feminista de libertação.
\end{abstract}

Palavras-chave: Bíblia. Descolonização. Feminismos. Teologia negra. Mundo afro-asiático.

\section{BIBLIA Y DESCOLONIZACIÓN: LECTURAS DESDE UNA HERMENÉU- TICA BÍBLICA Y FEMINISTA DE LIBERACIÓN}

\begin{abstract}
RESUMEN
Este artículo hace una revisión histórica del proceso de negación del aporte intelectual e académico de los descendientes de africanos desde tiempo memorables hasta el debate contemporáneo de los
\end{abstract}

* Pós-doutorado em Hermenêutica Feminista Latino-Americana na Escola Superior de Teologia, São Leopoldo Brasil. Doutor em Ciências da Religião na área da Bíblia pela Universidade Metodista de São Paulo - Brasil. Professora na Faculdade de Teologia da Universidade Santo Tomás. ORCID: https://orcid.org/0000-0001-5958-0570.Email: maricelmena@usantotomas.edu.co.

** Estudos de pós-doutorado em Educação - Ciências Sociais e interculturalidade. Doutora em Filosofia e Ciências da Educação. Professora dos Doutorados em Educação da Universidade Santo Tomás, Bogotá e da Universidade San Buenaventura Cali. ORCID: https://orcid.org/oooo0001-7014-047X E-mail: claudiavelez@ustadistancia.edu.co

*** Pós-doutorado em Educação, Ciências Sociais e interculturalidade pela Faculdade de Educação da Universidade Santo Tomás, em Bogotá, Colômbia; Doutor em Teologia pela Escola Evangélica da Universidade de Hamburgo, Alemanha. Atualmente é professor da Faculdade de Teologia da Universidade Santo Tomás e do Centro de Treinamento Teológico da Pontifícia Universidade Javeriana, em Bogotá. ORCID: https://orcid.org/0000-0001-6194-0192 E-mail: loidasardinas@ usantotomas.edu.co 
estudios culturales, rescatando especialmente, el aporte de las mujeres en los estudios del trasfondo afro-asiático en la Biblia hebrea y cristiana desde una teología negra y feminista de liberación.

Palabras-clave: Biblia. Descolonización. Feminismos. Teología negra. Mundo afro-asiático.

\title{
BIBLE AND DECOLONIZATION: READINGS FROM A BIBLICAL AND FEMINIST LIBERATION HERMENEUTICS
}

\begin{abstract}
This article provides a historical review of the process of denying the intellectual and academic contribution of the descendants of Africans from the earliest times to the contemporary debate of contemporary cultural studies, especially rescuing the contribution of women in the studies of the Afro-Asian transfusion in the Hebrew and Christian Bible from a black and feminist theology of liberation.
\end{abstract}

Keywords: Bible. Decolonization. Feminism. Black theology. Afro-Asian world.

O ser humano é barro e palha

Deus é seu arquiteto.

Ele destrói e constrói diariamente

Cria a mil inferiores

De acordo a seu gosto

Converte a mil pessoas em supervisores

Instruções de Amenemope, XXV.

Novo Império (1542-1069)

\section{INTRODUÇÃO}

Iniciamos este ensaio com os ensinamentos de Amenemope, porque consideramos importante, ao falar da descolonização da Bíblia, no horizonte afro-asiático, reconhecer que muitos gêneros bíblicos não foram exclusivos do povo israelita. Existem importantes paralelos no jeito de contar a história do povo de Israel com a maneira como os antigos africanos o faziam, isto é: mediante mitos, epopeias, ditos, parábolas, sentenças, entre outros, que sem dúvida alguma evidenciam que a colonização, o centrismo e o ocultamento do legado sapiencial feminino não são algo recente. De fato, o lugar de cultivo desse tipo de literatura de corte sapiencial é na aldeia, no espaço de socialização 
entre mães e filhos. Nesse contexto, muitas máximas ou instruções sobre os perigos e as armadilhas da vida que conduzem à morte, são proclamadas oralmente pelas mulheres aos seus filhos nesse espaço de socialização e instrução feminina, a aldeia. Na transição da tradição oral ao texto escrito, a patente feminina de muitos desses ditos se perde e são apropriadas pelos escribas da corte.

A Instrução de Amenemope é uma obra literária composta no Antigo Egito (Império Novo, provavelmente perante o período Ramassida, contém trinta capítulos de conselhos para uma vida exitosa, supostamente escritos pelo escriba Amenemope como um legado para seu filho Kanakht. Essa obra reflete sobre as qualidades internas, atitudes, e comportamentos necessários para uma vida feliz em situações, circunstâncias sociais, e econômicas cada vez mais difíceis. É amplamente considerada como uma obra maestra da literatura sapiencial antiga. Esses ensinamentos têm despertado grande interesse pelos estudiosos do Antigo Testamento. Quando Wallis Budge (1924) publicou a inscrição, notou-se imediatamente a similitude com o livro de Provérbios 22.

Instruções de Amenemope, cap. 1): "Dá o teu ouvido e ouve o que eu digo, e aplica o teu coração para apreender. É bom para ti para colocá-los no teu coração, deixe-os descansar no cofre do teu ventre, para que eles possam atuar como um pino sobre a tua língua" (Pr. 22,17-18)

(Instruções de Amenemope, cap. 1): "Dê os teus ouvidos, ouça as palavras que são ditas, dá o teu coração para interpretá-los" (Pr. 22,17-18)

(Instruções de Amenemope, cap. 2): "Acautela-te de roubar os pobres, e oprimir os aflitos" (Pr. 22,22-23)

(Instruções de Amenemope, cap. 6): "Não retire o marco dos limites do campo, e não viole o limite das viúvas" (Pr. 22, 15. 25).

Essa sabedoria nos oferece elementos importantes para a compreensão da antiga visão antropológica dos egípcios e também dos israelitas, para quem o coração é o lugar privilegiado para o entendimento. Há pois uma relação estreita entre os ouvidos, o coração e a língua, é um ir e vir. Os ouvidos escutam aquilo que o coração sente. A sabedoria implícita nesses trinta conselhos da vida prática é uma exortação 
necessária para uma saudável convivência, em que a opção preferencial pelos pobres e afligidos já é parte constitutiva da antropologia africana, porém somente é reconhecida como um legado semita.

Esta introdução, à maneira de prolegômenos, nos situa no horizonte desse escrito onde se faz uma crítica ao colonialismo, desde uma leitura hermenêutica negra e feminista crítica, que parte do lugar de resistência religiosa, cultural e social das mulheres pobres e negras. Uma leitura que se preocupa pelas situações concretas de racismos, colonialismos, classismos, sexismos e antissemitismos que marcam as experiências de vida das maiorias marginalizadas das nossas sociedades. Gostaríamos de ajudar na busca de sentido às nossas experiências humanas para juntos tentar superar as injustiças, desigualdades, opressões provenientes das ideologias colonialistas que imperam nos discursos bíblico-teológicos, para apontar caminhos de construção de relações sociais que garantam a dignidade de vida, especialmente para as mulheres pobres e negras.

Num primeiro momento, apresentamos um percurso histórico sobre a emergência das teologias negras feministas no continente. Em seguida, fazemos uma breve análise acerca do surgimento da consciência negra e dos estudos pós-coloniais para logo resgatar os aportes do feminismo negro ao pensamento decolonial. Após isso, exibimos um pequeno itinerário a respeito do tema da descolonização desde o feminismo negro, na Bíblia, e concluindo apontamos algumas considerações finais em perspectiva decolonial.

É importante ter em conta nesse percurso que o que aqui chamamos de teologia negra e feminista de libertação, é uma corrente teológica crítica que, apesar de ser filha da teologia da libertação, toma rumo próprio ao reconhecer os limites de uma teologia centrada no pobre maioritariamente masculino. Nesse sentido, nossa teologia leva a sério a vida das mulheres pobres e negras na sua tripla discriminação e a situa em contexto como construtora de conhecimento.

\section{GÊNESE DA TEOLOGIA NEGRA FEMINISTA NA AMÉRICA}

Podemos caracterizar a emergência da teologia negra feminista de libertação em quatro momentos, que nem sempre correspondem a uma organização cronológica, pois nas comunidades afro os conceitos 
tempo e espaço são diferentes ao cronos ocidental. Quer dizer, cada fase não é vista como uma superação da anterior. Constantemente vamos e voltamos e nos projetamos para um futuro.

$O$ primeiro momento remonta aos séculos $X V$ e $X V I$, época em que as africanas e os africanos eram comercializados como mão de obra barata pela Espanha, Portugal, Inglaterra e França. Porém, abrange séculos anteriores, pois a história negra já se iniciara no continente africano. Desde esse tempo, se registra uma longa história de escravidão e resistência que durou por mais de três séculos (Richard RALSTON, 1993, p. 875-918). Muito religiosos, os africanos encontraram um importante potencial para a sua libertação, visto ter havido "inúmeras rebeliões, boicotes, petições, fugas, incêndios, assassinatos (especialmente por veneno), automutilações, insurreições" (Leonardo KARNAL, 2007, p. 65). Eram inspirados na fé cristã, na qual as mulheres certamente participaram. Sua resistência também provém das canções religiosas e espirituais entonadas nas plantações durante o trabalho e das práticas mágicas, da arte do bem querer e dos rituais religiosos (Adriana MAYA, 2002, p. 103). ${ }^{1}$ A arte do "Bem querer" consiste em:

Preparação de poções, banhos, unguentos e amuletos para preencher aos amantes ou aos maridos infiéis (...) sua toma resultava insuficiente se não estava acompanhado de orações e conjuros apropriados.

As mulheres participaram também nos processos de luta pela emancipação. Na Venezuela, por exemplo, Guiomar, companheira do negro Miguel (1552), combateu junto dele na rebelião dos escravos, sendo proclamada rainha.

O segundo momento da teologia negra feminista de libertação inclui ainda as lutas pela emancipação dos movimentos abolicionistas (século XVII) e se estende até finais da década dos anos de 1960. Essa fase, é caracterizada por uma crítica radical ao racismo institucional. Esse período foi marcado pela luta das negras e negros cristãos contra as instituições escravocratas que mantiveram a ideologia separatista.

Uma particularidade da mulher quilombola "cimarrona" é sua convicção do controle da sua própria sexualidade. 
Nesse século, a rainha Wiwa, esposa de Benkos Biojó, assumiu a liderança do projeto emancipatório, após a morte de seu esposo, em 1621, no quilombo de San Basílio, na Colômbia. Juana Francisca, Polônia e Agustina, por sua vez, foram mulheres que também lideraram processos de resistência no mesmo quilombo. No século XVIII, Maria Valentina e Juana Llanos foram líderes das rebeliões em 1771-74, na região de Barlovento, na Venezuela. Luiza Mahin, no Brasil, também participou dessas rebeliões em Salvador Bahia. Se fizéssemos um inventario histórico das mulheres aguerridas, nesse período, nas Américas, a lista seria muito maior. $O$ fato é que sua luta silenciosa também incluiu a busca de zonas livres das colônias como alternativa social, política e econômica ao sistema escravagista.

Por sua vez, o feminismo negro nos Estados Unidos surgiu na tensão entre o abolicionismo e o sufrágio, na segunda metade do século XIX. Esse movimento surge das comunidades que foram submetidas física e moralmente a todo tipo de maus-tratos. Mulheres, como Harriert Tubman, que conseguiram escapar da escravidão e se incorporaram à rede de combate ao racismo, em 1849. Como Sojourner Truth (17971883) conhecida pelo seu discurso "não sou eu uma mulher?" Esse é um feminismo que não nasce no escritório, mas na vida cotidiana das mulheres. Não é um feminismo segregacionista, já que teve como aliados os homens. Com eles partilhavam a luta pela abolição, e com as mulheres brancas participaram da luta pelo sufrágio feminino. É, porém, um movimento interclassista. No ano de 1865 , se recebe a emenda que abolia a escravidão, isto é, a ruptura da diferença entre um homem livre e um escravo, do negro com o branco. Essa emenda estendeu o direito do voto aos homens negros. Mas somente em 1920 esse direito é concedido também às mulheres brancas e às negras.

Já nos inícios do século XX se percebe uma migração dos setores rurais aos urbanos, emergindo então um feminismo negro adscrito à classe trabalhadora. No transcurso das três primeiras décadas, as canções e sonatas oriundas do período anterior deram origem ao blues (Hernán PRADA, 2015), ${ }^{2}$ que pronto se converteria no espaço onde circularia o

O blues, inicialmente, são canções de oração e de trabalho. Nessas canções se expressam, mais do que tudo, os sentimentos de tristeza, alegria, melancolia, enfim, são as emoções que falam. 
discurso oculto das mulheres. Essa expressão musical falava do corpo, dos desejos, do controle feminino da sua própria sexualidade, isto é, da sua experiência vital como mulheres pobres negras e operárias.

Nas duas décadas seguintes, as migrações continuaram do Sul ao Norte, do mesmo modo que cresceu a segregação racial. Porém, é durante as décadas dos anos 50 e 60 que se deram diversas transformações, entre outras coisas pelo emergir do Movimento pelos Direitos Civis. Novos atores e atrizes irromperam no cenário político. Foi assim que, no ano de 1955, Rosa Parks, ${ }^{3}$ pioneira desse movimento, se negou a ceder seu lugar no ônibus a um branco. Ela foi presa e esse acontecimento gerou protestos por todo o país. Porém, na História quase sempre é rememorada a liderança do pastor batista Martim Luther King (1929-1968) e do líder dos movimentos negros muçulmanos Malcom X (1925-1965), e de outros movimentos como o pan-americanismo, onde a liderança das mulheres é invisibilizada.

O terceiro momento se inicia na segunda metade da década dos anos de 1960, período da emergência da produção teológica acadêmica da Teologia Negra Norte-americana que, entre outras coisas, já leva implícita a opção preferencial pelos pobres legada dos períodos anteriores, e vai até finais dos anos de 1970. Nesse contexto, no ano de 1964 a lei pelos Direitos Civis promulga "o fim" do racismo e da discriminação.

Nessa fase, se destacam o trabalho de James Cone e de outros acadêmicos norte-americanos. Entre eles, podemos nomear as teólogas negras Theressa Hoover e Jackelyn Grant (Rosino GIBELLINI, 1998). Na América Latina, à luz da Teologia da Libertação, as comunidades começaram a questionar o papel do povo negro dentro da categoria de pobre. Assim, se estabelece uma correlação entre racismo e classismo, visto que a maioria dos pobres do continente apresenta essas duas características. Não é o mesmo "ser pobre" do que "ser mulher pobre e negra".

A quarta etapa vai desde a década dos anos de 1980 até os nossos dias. Além da crítica ao sistema capitalista, as mulheres negras constataram o fato de que o trabalho da teologia negra tinha em destaque somente homens. Muitos teólogos negros permaneceram em silêncio

Rosa Parks (1913-2005) ativista pelos direitos civis dos negros nos Estados Unidos. 
sobre a situação das mulheres, mesmo cientes de que mais da metade da população, e das igrejas negras era constituída por mulheres. Assim, à correlação entre o racismo e o classismo acrescenta-se o sexismo, que visa desconstruir as assimetrias de gênero presentes nas nossas construções de pensamento. Em efeito, o evangelho não pode ser real num contexto de marginalização, sexismo e ocultamento da situação das mulheres nas igrejas e na sociedade. Nos anos de 1980, pranteia-se o problema dos feminismos brancos, questiona-se o heterossexismo epistêmico presente no pensamento político feminista de cunho ocidental. A teóloga Dolores Williams (1985), por exemplo, argumenta o seguinte:

1. Há ambiguidades nos feminismos pelo que também estes são racistas

2. O patriarcado e o poder institucional dão possibilidades de promoção unicamente às mulheres brancas

3. As mulheres negras são invisibilizadas dentro do movimento feminista

4. São discriminadas pelo sexo, gênero e raça.

Essa teóloga introduz, ainda, o termo mulherista (womanism) para assumir a teologia e a interpretação bíblica feminista negra norte-americana (Dolores WILLIAMS, 1985, p. 440). Planteia-se, então, uma questão ética para a teologia cristã que, segundo ela, é responsável também pela reprodução de ideologias racistas e sexistas.

\section{DA BLACK THEOLOGY À CONSCIÊNCIA NEGRA}

No Caribe, na metade do século XX, e mais concretamente na Jamaica, debaixo da liderança do pregador jamaicano Marcus Garvey (1887-1940), consolida-se o movimento Rastafari, que surge entre os mais pobres dos pobres, os descendentes dos antigos quilombolas da ilha. Paradoxalmente ao que argumentamos, esse parece um movimento de homens, pois, de fato, esse movimento tira as mulheres do cenário e dá o protagonismo somente aos homens, tendo de fundo a tradição judaica legada da Etiópia (Kebra NAGASH, 2010). ${ }^{4}$ Esse movi-

4 Na história da religião da Etiópia, especialmente dos judeus negros da Abissínia, acredita-se que a religião chegou via Salomão e a rainha de Sabá. 
mento converteu-se rapidamente na base cultural da resistência negra na diáspora americana. Como afirma César Bou (2009):

Foi o primeiro passo na reconstrução da uma consciência cultural africana. Porém não pode haver consciência sem história, e a história rasta era uma história mítica. Havia que construir uma história real, para pôr em pé uma consciência secular (p. 62).

Paralelamente, em 1960, o gênero musical chamado reggae surgiu como a maior expressão de uma espiritualidade de resistência, onde os temas da pobreza, crítica ao poder e à discriminação racial poderiam ser uma gênese do que mais tarde foi chamado de Teologia da Libertação. Porém, mais uma vez, testemunhamos a negação e a falta de reconhecimento histórico de nosso legado intelectual. "Prefiro um túmulo a viver como um escravo, tão certo como o sol brilha hoje, eu terei aquilo que me pertence" (Jimmy Cliff, em sua música The Harder They Come).

Sem dúvida alguma, o grande precursor da consciência negra foi o senegalês Cheik Anta Diop (1923-1986), que desde a historiografia contribuiu na necessidade de reconstruir a história das nações colonizadas. Em suas palavras: "ao redescobrir nosso passado, temos buscado um meio de recriar essa consciência histórica sem a qual não pode haver uma grande nação" (Cheik Anta DIOP, 1968). Entre seus argumentos contundentes para a futura reelaboração teórica pós-colonial, situamos sua reivindicação da africanidade do Egito Antigo. A antiguidade egípcia é à cultura africana o que a antiguidade greco-latina é à cultura ocidental. A construção de um corpo de ciências humanas africanas deverá partir desse fato (Cheik Anta DIOP, 1983).

O trabalho de Diop, fundamentado na análise diacrônica, comparativa, crítica, e multidisciplinar, e sua ideia de elaboração de uma História Geral da África, consolida-se em 1974, no Cairo, perante o Colóquio sob "o povoamento do Egito Antigo e a decodificação da escritura meroítica”, convocado pela UNESCO (César BOU, 2009, p. 66). Outra obra que deve ser mencionada como pioneira é o Legado Roubado "Stolen Legacy" (1954), do professor George James, que desenvolveu sua obra paralela à de Diop na Guiana Britânica. Esse autor, sem conhecer a obra de Diop, analisa a influência da cultura egípcia no mundo mediterrâneo, 
assinalando que a cultura grega é uma cópia do pensamento egípcio (César BOU, 2009, p. 82). No ano de 1987, o linguista britânico Martin Bernal é o primeiro a valorizar a obra de James e a sua obra, Atena Negra: As raízes afro-asiáticas da civilização ocidental, coincide com a tese de James, reconhecendo o legado egípcio na cultura grega (Martin BERNAL, 1993).

Martin Bernal (1993) afirmava que a compreensão do mundo, a partir do modelo ariano, era recente, propondo voltar para o modelo antigo revisado, no que se reconhece as raízes africanas nas origens da antiga civilização mediterrânea (Maricel MENA-LÓPEZ, 2017, p. 79). Martin Bernal asseverou que a compreensão do mundo, a partir do modelo ariano semítico (filhos de Shem), pertence ao século XIX, propondo o retorno ao modelo antigo revisado, que obrigaria a repensar as bases fundamentais da chamada "Civilização ocidental" na historiografia (Martin BERNAL, 1993, p. 11). Nesse modelo, os povos do horizonte africano (Camitas, filhos de Cam) teriam influenciado os povos do Mediterrâneo e não o contrário, como habitualmente ensinaram.

A tendência recorrente dos positivistas é a desqualificação histórica dos mitos e das genealogias, porém, essa contribuição, para alguns exegetas negros tem sido fundamental, sendo possível demonstrar em que medida a cultura judaica tem sua gênese nas tradições míticas e genealógicas africanas.

Na narrativa mítica do paraíso de Gênesis 2,10-14 encontramos a mais antiga menção do chamado crescente fértil, que vai desde os rios Tigre e Eufrates até o Nilo. O Éden ali descrito se estende à Etiópia (Cush em hebraico), isso é evidente. No entanto, os estudiosos da Bíblia insistem que o rio que circunda a terra da Etiópia seria um afluente do rio Jordão. Edward Ullendorff (1988), por sua vez, afirma que o rio Giom, que cerca toda a terra da Etiópia é uma adaptação do curso do Nilo a Meroé e Abissínia.

A distribuição geográfica dos descendentes de Noé é dada, após um breve resumo (10: 1-32). Essa genealogia, que representa uma longa era, sugere áreas nas quais as diversas famílias migraram. Jafé e seus filhos foram colocados nas imediações dos mares Negro e Cáspio, estendendo-se para o oeste em direção à Espanha (10: 2-5). Muito 
provavelmente, os gregos, os povos indo-germânicos e outros grupos afins descendiam de Jafé.

Os três filhos de Cam eram habitantes da África (10: 6-14). Posteriormente, expandiu-se para o norte, e para a terra de Babilônia e Assíria, a construção de cidades como Nínive, Calá, Babel, Akkad e outras. Canaã, o quarto filho de Cam, estabeleceu-se ao longo do Mediterrâneo, que se estende desde Sidom a Gaza e leste. Cam e seus descendentes ocuparam a área norte do Golfo Pérsico (10: 21-31). Elam, Asur, Aram e outros nomes de cidades foram associados aos semitas. Depois de 2000 a.C., cidades como Mari e Nahor se tornaram centros de destaque da cultura semítica.

A questão que se coloca nesse percurso é o porquê a insistência numa origem semita do povo de Israel, se o modelo antigo testemunhado na Bíblia entende que a África teria influenciado a cultura semítica? Por que não dizer o que precedeu o semitismo?

Até aqui parece haver uma ruptura epistêmica com as aproximações anteriores. Parece que as mulheres pouco ou nada tiveram nesse processo. Os intelectuais negros excluíram sua contribuição das etapas anteriores, desconhecendo seu papel na História. Não obstante, elas estiveram ali, disseminadas no meio da discussão dos varões negros (Jarid ARRAES, 2017).

\section{DA CONSCIÊNCIA NEGRA AOS FEMINISMOS PÓS-COLONIAIS}

Na América Latina, o feminismo pós-colonial se consolida a partir dos anos 70, denunciando o desumano sistema escravista e racista, propondo uma linha de pensamento que integra o saber próprio dos afro-americanos e uma crítica ao capitalismo. Já na década dos 80 e 90, a ênfase recai sobre o reconhecimento do legado que deixaram as colônias africanas aos diversos contextos da África, Ásia, Europa, e de modo geral, à diáspora. É uma crítica ao eurocentrismo epistêmico monocultural ocidental.

Foi na década dos anos de 1990 que as mulheres na América Latina começaram a pensar na possibilidade de reivindicação dos seus direitos desde uma perspectiva social, cultural e política. Assim, no ano de 
1992, em Santo Domingo, realizou-se o Primeiro Encontro de Mulheres Afro-latino-americanas e Afro-caribenhas, com o intuito de reivindicar o trabalho histórico das mulheres no meio de discriminações constantes.

A categoria pós-colonial, como ferramenta analítica e prática crítica, tem uma grande importância para compreender e abordar a história e a complexidade de muitos fenômenos culturais e políticos inerentes a quase todas as sociedades contemporâneas (Sidi MOHAMED O, 2007, p. 18).

O pensamento descolonial, por sua vez, é uma posição epistemológica das ciências sociais, a partir de uma perspectiva do pensamento crítico latino-americano, que procura analisar a maneira como o mundo funciona hoje; isto é, a política globalmente e também analisa as relações sociais, a partir de modelos e teorias do conhecimento que servem para interpretar as diferentes "temporalidades e localidades do poder" (Melody FONSECA; Ary JERREMS, 2012, p. 103) e do conhecimento na América Latina (Santiago CASTRO-GÓMEZ, 2007).

Os principais questionamentos feitos aos pós-colonialismos têm a ver com o entendimento limitado de que essa categoria trata somente temáticas relacionadas com práticas culturais e sua limitação à análise de práticas de textos pós-estruturalistas de algumas figuras contemporâneas, e pela supervalorização do pensamento anticolonialista, além do mais pela sua crítica ao saber acadêmico disciplinar, inclusive chega-se até a ridiculizar esse pensamento, como bem o faz Ella Shohat (2008):

Não é possível derrotar as estruturas hegemónicas e seus marcos conceituais gerados durante os últimos quinhentos anos agitando a vara mágica do "pós-colonial” (p. 111).

De fato, não é uma vara mágica que destruirá as ditas estruturas hegemônicas, mas sim um câmbio de atitude em favor da vida em sua integralidade. E esse ideal de mudança e transformação já vem se forjando desde há séculos e desde as margens da oficialidade. Assim pois, a aposta por uma crítica ao pensamento colonialista não é nova. Ela tem suas raízes nos movimentos sociais-políticos-ancestrais e suas demandas pelo reconhecimento de direitos e transformação social (Catherine WALSH, 2018). 


\section{FEMINISMOS DECOLONIAIS}

O feminismo decolonial, ainda em construção, surge das ativistas negras e lésbicas, com um forte acento na análise antirracista e na crítica ao feminismo a às políticas de identidade na América Latina. É um movimento contemporâneo, que reivindica a voz subalterna, isto é, seu direito de ser e existir além dos parâmetros hegemônicos das epistemologias ocidentais.

Os estudos decoloniais vindicam a necessidade de uma descolonização do ser, do saber e do poder (Santiago CASTRO-GÓMEZ, 2007). O conceito de colonialidade do poder é utilizado por Anibal Quijano (1997) para articular dois eixos: o poder global capital-trabalho, com um mundo onde o racismo permeia a economia política e as diversas formas de poder (Franz FANON, 1983), que fazem parte da infraestrutura latino-americana. $\mathrm{O}$ racismo constitui um fator determinante na divisão social do trabalho e na acumulação do capital a escada mundial. Esse conceito tem sua gênese nas correntes descoloniais e pós-coloniais que o antecedem da diáspora africana. Assim, a afirmação de Quijano de que "o racismo constitui um fator determinante na divisão social do trabaIho e na acumulação de capital em escala mundial" (Aníbal QUIJANO, 2014, p. 83) foi detectada pelos abolicionistas que o precederam. Então, por que continuamos a roubar a patente da contribuição intelectual de nossas tradições ancestrais?

A colonialidade do saber se refere à epistemologia eurocêntrica, isto é, ao jeito como o ocidente se vende a si mesmo como o pensamento racional mais evolucionado na História (Aníbal QUIJANO, 2014, p. 83). Isso já foi criticado por Gamal Mokhtar, Cheikh A. Diop, J. Yoyotte, Riyadh, A. Hakem, Ki Zerbo, entre outros intelectuais africanos, que reconstruíram a História a partir de epistemes africanas (Gamal MOKHTAR, 2010).

A colonialidade do ser tem a ver com a identidade, a construção e a produção do ser..$^{5} \mathrm{~A}$ colonialidade do ser nasce da negação do ser

Projeto integrado por acadêmicos de diversas disciplinas como a história, a sociologia, a antropologia, a filosofia entre outros e de diversos países do continente. Entre seus representantes, temos o filósofo colombiano Santiago Castro-Gómez, o sociólogo de Porto Rico Ramón Grosfoguel, o sociólogo peruano Aníbal Quijano, o sociólogo científico norte-americano Inmanuel 
colonizado, que o identifica com a condição de não ser, e dizer, do colonizado. Este é talvez o ponto mais trabalhado pelos intelectuais negros e negras ao resgatar não somente a contribuição dos povos africanos nas ciências, senão também no reconhecimento de saberes outros. Isto sem dúvida contribuiu para a construção de uma identidade negra emancipada.

$\mathrm{Na}$ Colômbia, o giro decolonial é abandeirado pelo grupo de investigação nomeado "Projeto latino/latino-americano modernidade/ colonialidade" do Instituto Pensar, da Pontifícia Universidade Javeriana, em 1999. E suas publicações giram em torno de geopolíticas do conhecimento e da colonialidade do poder baixo à liderança de Santiago Castro Gómez (2007). Como já afirmamos em nota anterior, o pós-colonialismo, como teoria crítica desde a sua gênese, deu atenção à geopolítica da exclusão do Ocidente, bem como, à sua reivindicação de possuidores do ser e do conhecimento.

Como teoria crítica, o pós-colonialismo começou, em 1947, com os processos emancipatórios asiático e africano, que produziram o colapso das bases geopolíticas colonialistas fundadas desde o século XVI. Embora seja verdade que houve diálogos entre as teorias pós-coloniais da Ásia, África e América Latina, a partir da análise do sistema-mundo e das teorias latino-americanas sobre colonialidade, o que resta a reconhecer é que essa contribuição serviu para a restauração de ciências sociais latino-americanas.

O pensamento decolonial é uma postura epistêmica das ciências sociais, desde uma perspectiva do pensamento crítico latino-americano, que tenta analisar a maneira que o mundo se desenvolve na atualidade, quer dizer, a política global e suas relações sociais desde modelos e teorias do conhecimento que servem para interpretar as diferentes temporalidades e localidades do poder e do saber na América Latina (José María BARROSO, 2014, p. 22-33).

$O$ pensamento decolonial realiza uma crítica à racionalidade ocidental, desde a alteridade a partir do método analéctico, isto é, pensar

Wallerstein, o sociólogo equatoriano Agustín Lao Montes, o semiólogo argentino Walter D. Mignolo, a pedagoga e linguista equatoriana-estadunidense Catherine Walsh, o filósofo de Porto Rico Nelson Maldonado-Torres, o sociólogo venezuelano Edgardo Lander, entre outros 
desde a diferença, desde a crítica dos sujeitos que estão fora do sistema: afros, indígenas, roms, LGBTI etc., os quais historicamente têm sido discriminados e invisibilizados.

Não se trata de redescobrir "tradições" ancestrais contrapostas tanto no plano historiográfico como no político - à modernidade ocidental - trata-se mais bem de trabalhar na construção de uma estrutura mais complexa do que a própria modernidade, para se abrir sem dúvida ao reconhecimento de uma pluralidade de modernidades, determinadas pelas diferentes formas de adoção em diferentes contextos históricos e geográficos pelo encontro/colisão entre história e histórias (Sandro MENDOZA, 2008, p. 23).

No campo da educação e dos estudos teológicos afro-americanos, é necessária uma descolonização do conhecimento, entendida neste escrito como o reconhecimento e valorização das contribuições dos afrodescendentes ao desenvolvimento das nações. Nesse sentido, criticam-se os universalismos, isto é, aqueles conhecimentos, práticas e metodologias que se aplicam a todas as esferas e contextos da ciência e do conhecimento.

O pensamento descolonial, por sua vez, permite que narrativas testemunhais afro-americanas sejam "recontadas" desde outros contextos, valores, e reconhecem isso como um processo de reconstrução do conhecimento, questionando, assim, o eurocentrismo institucionalizado. $O$ testemunho como gênero reivindica o direito a pôr em cena os aspectos não contados e excluídos da historiografia oficial. É isso que Monika Walter (1992) avisa:

[...] redescobrir o ato de escrever que suponha um consenso e uma participação coletiva, este é o método narrativo da novela testemunho, ou melhor, da cimarronajem estética do texto ... um retorno ao literalismo, que consiste [...] na recriação da oralidade (p. 201).

Essa história testemunhal pode ser analisada a partir da categoria geopolítica do conhecimento cunhada por Walter Mignolo, segundo a qual a pessoa é descolonizada intelectualmente e epistemicamente numa dupla dimensão: por um lado, mostrando a correlação existente 
entre o lugar geocultural e a produção teórica mediatizada pelo poder. Por outro, incorporando o conhecimento dos marginalizados nos espaços de produção e reprodução do conhecimento (Paola OJEDA, 2010, p. 156). Assim pois, proclamamos o direito de contar a história desde nossos próprios testemunhos que, ao longo do tempo, foram socavados e que hoje mais do que nunca estão demostrando que desde o continente mãe seus filhos e filhas da diáspora seguem fazendo justiça em favor do reconhecimento pleno, e de uma vez por todas, dos saberes produzidos desde as margens das exclusões.

\section{BÍBLIA E DESCOLONIZAÇÃO DESDE A TEOLOGIA NEGRA FEMI- NISTA}

O tema da descolonização nos estudos bíblicos não é novo. Surge de um processo crítico afunilado a partir da Segunda Guerra Mundial, no que se questiona a relação de interdependência política e econômica de um território ou colônia com relação a uma nação estrangeira, neste caso, dos habitantes nativos africanos que faziam parte do crescente fértil antigo com os israelitas.

Assim sendo, o pensamento descolonial revisa a tradição bíblica e descobre que os povos do horizonte afro-asiático deixaram um importante legado na religião de Israel. Rompe com padrões e valores preestabelecidos pela tradição ocidental e questiona o acesso ao conhecimento eurocêntrico. Ou seja, um modelo epistemológico universal para todos os povos e culturas. Questiona as epistemologias das matrizes eurocêntricas, reconhecendo que são construções criadas e perpetuadas ao longo do tempo. Ou seja, pertencem a épocas e espaços entendidos como definitivos. Essa epistemologia ignorou o antigo paradigma do conhecimento criado por pessoas e culturas da antiguidade, focalizando somente o modelo ariano. Nesse modelo historiográfico, os chamados grupos periféricos não foram contemplados. Assim, pergunta-se por que a ciência bíblica ignora as raízes africanas presentes na sua história, enquanto elas também estão presentes nas tradições bíblicas (Maricel MENA-LÓPEZ, 2006).

No processo de reconstrução da consciência negra na Bíblia, tomamos como ponto de partida que tanto o judaísmo como o cristianismo 
são religiões da "memória". Os fatos históricos permaneceram na memória do povo ao longo do tempo, assim como o espaço e tempo onde são registrados os acontecimentos. Nesse fazer memória, descobrimos que as mulheres negras são responsáveis pela preservação da memória oral, que possibilitou que a história não perecesse no tempo. Estes dois elementos, preservação e memória, foram o elo condutor que nos permitiu determinar o carácter simbólico e ideológico das interpretações.

Porém, o grande paradoxo é que o texto bíblico que através da história ocidental serviu para legitimar a opressão e marginalização do povo negro se converteu numa ferramenta fundamental para a interpretação de nossa luta e resistência. Assim, num primeiro momento da nossa caminhada hermenêutica, nos identificamos com a luta pela libertação da escravidão do povo israelita. Acreditávamos que o Deus bíblico também se fazia presente no êxodo experimentado pelos africanos no período da colonização europeia e em nossos dias.

Num segundo momento, percebemos que no Novo Testamento Jesus se fazia presente em nossa caminhada ao optar pelos mais pequeninos/nas de nossa sociedade. A partir desses elementos, começamos a perceber a presença do povo etíope no Israel Antigo. Descobrimos que nos textos bíblicos os povos africanos são artífices da história da salvação, fazendo particular ênfase no aporte das mulheres nesse processo.

Desse modo, descobriu-se que as referências bíblicas sobre a terra de Cush, ou Etiópia, como eram designados os povos negros na Bíblia, eram numerosas e significativas (Gn 2,20-14, Gn 9,18-27, Is 11,11, Is 18,12, Am 9,7, Sf 1,1, Jó 28,18-19). Porém, a alusão específica às mulheres negras, igual ao conjunto das mulheres bíblicas, é muito pouco. Mas elas sempre aparecem em momentos significativos da História. As figuras femininas que confirmaram a participação das negras na história da salvação são: Zípora, mulher de Moisés ( Nm 12,1), a sulamita de Cântico dos Cânticos (Ct 1,5), a rainha de Sabá (1 Rs 10,1-13) e a rainha Candace (At 8,26-40). Essas figuras se convertem em referências de interpretação para as mulheres que releem os textos bíblicos desde a ótica negra e feminista. 


\title{
6. DE SACERDOTISAS E RAINHA A ESCRAVAS
}

\section{1 ZíPORA, A ETÍOPE, ESPOSA DE MOISÉS}

\author{
E isso aconteceu na estrada, numa pousada \\ E Yahweh achou e quis matá-lo. \\ E Zípora tomou uma pedra afiada e cortou o prepúcio de seu filho. \\ E ela tocou seus pés e disse: Certamente marido de sangue você é \\ para mim \\ E assim Ele o libertou e disse: Marido de sangue pela circuncisão (Êx \\ 4:24-26).
}

Essa mulher que emerge das sombras de seu pai (Reuel/Jethro) e seu marido (Moisés) aparece como a salvadora de seu esposo de uma situação misteriosa e perigosa. Moisés está em perigo mortal e ela realiza um ato de expiação oferecendo a Deus uma parte da masculinidade de Moisés. Zípora se lança como a salvadora de Moisés, ela enfrenta o ataque divino realizando o ritual da circuncisão. Ela corta o prepúcio de seu filho, toca os pés (órgãos genitais) e pronuncia as palavras "certamente você é esposo de sangue para mim" (v. 25). O termo "esposo de sangue" é enigmático, o fato de que o narrador do versículo $26 \mathrm{~b}$ tenta explicar a expressão sugere que a composição textual da frase era ambígua. Finalmente, o autor bíblico não explica como Zípora sabia que a maneira de livrar seu esposo dessa situação ameaçadora era fazendo esse ritual de circuncisão. Mas podemos intuir que é um Deus conhecido por ela, um Deus próximo. A intimidade que ela tem com Yahweh a faz encará-lo diretamente.

Não obstante, nas leituras colonialistas, sexistas e racistas, a memória do casamento de Moisés com uma mulher etíope, das regiões do Sul, Zípora (Nm 12,1-10), é responsável pelo castigo de Miriã, irmã de Moisés. Miriã foi castigada com lepra por murmurar contra seu irmão "por causa de uma mulher etíope" que desposara. Esse castigo que, antes de tudo, quer erradicar a luta de poder pelo sacerdócio feminino nas origens do povo, é invertido para a justificação de ideologias racistas.

Assim, a atenção dada à mulher se limita a habituais rixas entre mulheres por um homem e não pelo seu papel como líderes religiosas. 
O texto nos mostra uma mulher fazendo as vezes de um sacerdote varão. Ela em seu papel de sacerdotisa circuncida seu filho e o faz com um instrumento muito antigo, uma pedra de pedernal, isto em si nos está revelando que estamos perante um texto muito antigo. É ela e não seu pai Jetro quem introduz Moisés no Yahvismo mediante um pacto de sangue.

É Zípora, a sacerdotisa, quem realiza o Berit Milah. Berit significa aliança e Mila, cortar ou remover. Berit Milá significa então Pacto Santo. É o pacto que consiste em cortar e/ou retirar o prepúcio que cobre a extremidade do pênis, órgão reprodutor masculino. O Berit Milá é muito importante. É a maior santidade de todo o judaísmo, porque dele depende a união eterna de todo judeu com o seu Criador. Essa aliança divina é feita por um Mohel que deve ser, além de um perito nessa arte, um judeu (varão) com uma relação estreita com o espiritual. Um observador ativo de todas as leis da Torá, um judeu fervoroso e respeitoso com Deus; um indivíduo de conduta inquestionável. Enfim, um sacerdote honorável (Maricel MENA-LÓPEZ, 2007).

\section{2 A SULAMITA DE Cântico dos Cânticos}

Nota-se nos estudos bíblicos a particular ausência e falta de reconhecimento da contribuição dos povos africanos na religião de Israel. A história do judaísmo antigo é sempre interpretada desde uma episteme unívoca ocidental, que privilegia o componente semita da religião de Israel em detrimento da contribuição egípcia e etíope na história e cultura da antiga religião de Israel. Quando a presença desses povos se torna evidente, os autores se voltam para o que chamamos aqui de racialização.

Racialização se refere, por um lado, ao fato de pôr o elemento racial onde ele não existe ou não é importante, por outro, o fato de que os estudos bíblicos estão quase sempre filtrados por uma interpretação e uma escrita branca e ocidental que deixam de lado o papel histórico dos grupos considerados "não importantes" para a construção do judaísmo e do cristianismo, povos e culturas de origem africana, mulheres, entre outros, e privilegiam o aporte dos homens do horizonte semita ocidental branco. Porém, a branquitude, o androcentrismo e o classismo são a norma, na medida em que a negritude, as mulheres e os pobres constituem um desvio dessa norma. 
Um exemplo do que estamos dizendo é encontrado na frase tradicional "eu sou negra, porém formosa" (Ct 1,5), onde a partícula "e" do texto original massorético é alterado por, "porém".

A nota textual da Bíblia de Jerusalém entende que uma mulher queimada, que cuida das vinhas não pode ser mais do que uma escrava, ao contrário das mulheres com pele clara, como vemos a seguir:

Ela tem a tez bronzeada devido aos trabalhos do campo aos quais ela foi forçada, é comparada às tendas negras dos beduínos, tecidas com pêlo de cabra. Os antigos poetas árabes contrapõem a tez clara das meninas de bom nascimento (aqui as filhas de Jerusalém) aos escravos e escravas envolvidos no trabalho externo (Bíblia de Jerusalém, 1998).

É a Sulamita a protagonista do mais belo poema de amor existente na Bíblia Hebraica (Ct 1,5). Porém, sua corporeidade tem servido para a condenação do corpo, do erotismo, da sensualidade e da beleza dos corpos das mulheres negras, isto é, para a justificação de ideologias racistas sexistas e classistas. Por exemplo, Orígenes analisa a frase "sou negra, porém formosa" da seguinte maneira:

"Negra pela ignomínia da raça, porém formosa pela penitência e a
fé"; "negra pelo pecado, porém formosa pela penitência e os frutos
da penitência" (...) ela que é negra não é assim pela natureza nem
criada assim pelo criador, senão que sofreu esta situação acidental-
mente. "Assim é a situação dessa gente etíope, que tem uma negritu-
de natural que provém da sucessão carnal pois nestas passagens o sol
arde com maior intensidade e os corpos já queimados permanecem
na mesma forma pela sucessão do vício" "Do contrário sucede com
a negritude da alma: esta não se adquire pelo nascimento senão pela
negligência. A alma se tornou negra porque desceu. Mas quando
começa a subir, ela se torna branca e cândida: rejeitando a negritu-
de começa a irradiar a verdadeira luz" (ORíGENES, 1991, p. 107-129).

Essas leituras racistas que perduraram na exegese alegórica bíblica têm equiparado o fenótipo, isto é a cor da pele com o pecado. Porém, a crítica textual ao possibilitar a descoberta do sentido original dos textos possibilita a recuperação da identidade das mulheres negras. A 
partícula conjuntiva (e) do texto hebraico original, ajuda a recuperar a ideia original do texto. A partir dali as mulheres negras encontraram um caminho interessante para a recuperação da autoestima (Cleusa CALDEIRA, 2013).

\section{3. A RaINHA de Sabá, 1 ReIS 10, 1-10}

Perguntamo-nos, em primeira instância, pela situação geográfica de Sabá e por sua relação com a África. Os povos etíopes são associados com frequência aos habitantes da região de Sabá. Em Gênesis 10,7 e 1 Crônicas 1-9, o povo de Sabá aparece como neto de Cush, descendente da tribo camita e filha de Sem (semitas). As relações entre Cush e Sabá foram intensas mediante o comércio pelo mar Vermelho (cf. Is 18,1-2).

Essa terra era famosa pelas suas riquezas: pedras preciosas, ouro e aromas raros ( $1 \mathrm{Rs} 10,1,2,10)$. Sua gente é famosa por eles serem viajantes e mercadores, comerciantes de coisas finas e apreciadas em todas partes (cf. Ez 27,22-24). Falamos de uma terra amplamente conhecida nas narrativas bíblicas. Contudo, a história da rainha de Sabá foi sempre considerada uma narrativa folclórica, um mito lendário popular. Para muitos, o mito não é histórico, é uma criação cultural, para outros, por trás dos mitos existem histórias. O nosso texto parece ter raízes históricas concretas que nos remetem ao tempo do reinado de Salomão. Mas mesmo se tratando de um mito, para as comunidades negras, é muito importante a recuperação dos mitos não como algo falso, que contradiz a História. Pois todo mito nasce de um fato concreto, de uma vivência, de uma experiência comunitária. O relato da rainha de Sabá tem-se interpretado como um mito perdendo seu valor histórico. Mas ele não tem valor só como mito senão também como história.

O texto é claro, mostra a igualdade entre os monarcas, a mulher leva a palavra e aparece no centro da narração:

- Em Sabá vemos como as mulheres ocuparam cargos importantes, tornando-se rainhas do povo.

- Ela entra no palácio de Salomão com poder e sabedoria. Ela fala a ele tudo quanto tem em seu coração.

- Para a cultura hebraica, o coração é o lugar do entendimento, 
está ligado à razão é, porém, uma razão que passa pelos sentimentos.

- Muitos interpretam a expressão "não ouve palavra oculta que o rei não aclarasse a ela" (v. 3) como se fora uma competência de saberes onde há um ganhador e uma perdedora. Mas trata-se mais de um intercâmbio de saberes e esse reconhecimento não quer dizer submissão, embora rapidamente vejamos que essa é a intenção dos textos patriarcais.

- Ela observa a comida de Salomão e parece que por trás há uma crítica velada à opulência da mesa real.

- Essa crítica poderia sugerir o início do final da era dourada de Salomão.

Então o que uma rainha rica tem a dizer para o povo negro e pobre que vive hoje em condições de miséria?

Esse texto nos ajuda a perceber que historicamente tivemos riquezas e que hoje muitos de nós vivem na miséria graças às ideologias colonialistas, escravistas e racistas. Nos dias atuais, quando uma mulher negra usa ouro é porque furtou ou se prostituiu. De rainhas passamos a escravas, a cozinheiras, a mal assalariadas, a prostitutas e mães solteiras. O texto nos chama não só na recuperação da nossa autoestima mas a denunciar a situação de opressão que ainda vivem hoje as mulheres pobres e negras.

A história da rainha de Sabá, além de ser um mito para as mais diversas tradições, (Iemenita, judaica, etíope, cristã e muçulmana) tem sido vista como uma figura folclórica. É o mais claro exemplo de submissão e legitimação das mulheres à monarquia salomônica. É condenada até por muitas mulheres que veem nela uma mulher sem projeto político, como uma figura decorativa do patriarcado. Será que não é libertador o fato de termos uma monarca estrangeira e provavelmente negra com poder e sabedoria similar ao rei Salomão no século $X$ a.C., e mais ainda apenas comparada com o filho de Deus Mateus 12,42?

\section{4 A RAINHA CANDACE}

Muitos autores têm responsabilizado o mundo helenista pela expansão missionária da igreja africana representante dos "confins da terra" 
(At 8,26$)$, como consequência, a conversão é vista como realização profética das Escrituras cumpridas em Jesus. Por isso a salvação é oferecida a todos, também aos excluídos e afastados. Com isso observa-se a tradicional ideologia de universalização e colonização, onde o mérito é dado ao helenista Felipe e não ao etíope eunuco que vinha de adorar na sinagoga de Jerusalém.

A universalização e o colonialismo partem de uma leitura norte-sul, onde é justificada uma situação de subordinação religiosa por parte de um grupo dominante ocidental, neste caso, a Etiópia simboliza o homem do terceiro mundo, este Sul que reclama em nossos dias justiça ao norte. No entanto, não é possível definir o etíope-eunuco como marginal do Sul, sendo que de fato ele é um oficial com poder e prestígio.

Em consequência, nos perguntamos se podemos seguir legitimando esse tipo de leitura norte-sul que fala do sofrimento da África? Será que se deve continuar resgatando a "memória do sofrimento" como cordeiro degolado que recapitula as injustiças sofridas pelo continente? Ou, ao contrário, devemos ressaltar a "memória da vida". Nesse sentido, tomamos como exemplo que no reino da Etiópia o culto ao cordeiro exaltava fecundidade e força para esse povo criador de bois e cabras. Contudo, não negamos nem legitimamos o tratamento marginal que tem recebido esse povo que ainda sofre nos cantos do mundo. Acreditamos que hoje mais do que nunca devemos render um culto à vida, a essa vida plena da qual gozavam os antepassados africanos e da qual hoje se tem direito.

Nessa leitura de universalização vemos que a figura da rainha etíope é marginalizada pelos exegetas cristãos. De acordo com Renita J. Weems (1991), para a mulher afro-americana, a Bíblia expressa unicamente a possibilidade de acesso ao Deus cristão, negando com isso a possibilidade de acesso a outras manifestações religiosas. Desse modo, a mulher do texto, ao situar-se à margem do cristianismo, é pouco reivindicada. A mulher do texto é antagônica à realidade da mulher latino-americana, que de rainha passou a escrava, por isso o texto convida ao resgate de nossa dignidade de mulheres livres.

Essa rainha, igual à rainha de Sabá, não tem nome próprio. Candace é o título de uma linhagem de rainhas. Aqui o texto mais explícito se 
trata de uma soberana do povo etíope, embora não seja ela a personagem central do relato de Atos 8,26-40. São reveladoras as relações existentes entre Etiópia e Jerusalém, no primeiro século. Relações tanto comerciais como religiosas. O texto sugere que existiam relações diplomáticas e comerciais entre essas duas nações. O ministro do tesouro da rainha de Etiópia transita pelo território israelita, provavelmente por motivos comerciais. Mas, além disso, ele conhece o judaísmo. Vem de adorar na sinagoga de Jerusalém.

No versículo 26, é interessante ver que um dos sete diáconos que foram inicialmente eleito para a distribuição das mesas é agora um missionário itinerante. A ele se manifesta o Espírito Santo, que até o momento era exclusivo dos 12 apóstolos. A evangelização de Filipe é um mandato de Deus, e esse mandato não é casual e sim intencional, pois a iniciativa de conversão já tinha sito tomada pelos povos etíopes por livre vontade. Não foi uma imposição, como aconteceu posteriormente no período colonial.

O etíope vem de uma nação independente do domínio romano e é um judeu que vai à sinagoga, porém seu título de eunuco não se refere a um castrado físico e sim a um título real de ministro. Se não fosse assim, como seria possível um castrado orar na sinagoga? Vejamos algumas características desse personagem:

- Ele não é pobre, é um alto funcionário real que está a cargo do tesouro da rainha.

- Era um homem culto, pois podia ler o profeta Isaías em língua grega.

- Era um homem de fé, foi a Jerusalém para adorar.

- Um homem de prestígio e poder, pois podia ler o rolo sagrado e se preocupava por entender o que lia para aumentar a sua fé (v. 28-29).

- Toma a iniciativa do batismo, ao entender a mensagem.

Percebemos como sucedem as relações sociais entre a rainha e seu ministro e entre este e Felipe, intentando descobrir novas relações interpessoais. Ao aproximarmos o perfil cultural da comunidade etíope, ressaltamos a "dignidade" do povo etíope. Com isso queremos dizer, 
seu valor, seu poder e identidade como povo livre e independente do poder romano.

A rainha Candace não tem sido objeto de muitos estudos, ela, na maioria deles, é desapercebida. Toda a atenção é dada ao ministro eunuco. Ao reconhecer seu lugar de procedência, Etiópia, o texto de Atos 8,26-40 foi interpretado teologicamente como cumprimento messiânico. A missão helenística é tida como responsável pelo início do cristianismo na Etiópia do primeiro século.

No NT, vemos que a missão itinerante helenista é iniciada na África antes que em Roma. Isso de alguma maneira difere da fonte das origens cristãs quando afirma que a expansão missionária parte de Jerusalém passando pela Judeia e Samaria até chegar aos confins da terra, que seria Roma. Então o objeto central da missão seria atingir o mundo greco-romano. No entanto, percebe-se que, desde o início, a marcha da Palavra de Deus não se limita ao mundo romano, a missão vai da periferia para o centro. Ela vai além das fronteiras do império. Lucas aprecia o império, mas não lhe reserva exclusividade alguma.

Em termos gerais, pode-se concluir que a África negra sempre esteve presente na tradição bíblica ao lado dos grandes impérios, somente que a partir da linguagem de dominação esta passou a ser marginalizada. Portanto, Atos 8,26-40 não pode ser interpretado como cumprimento de universalização, por um lado, por ser parte da linguagem de dominação, por outro, porque a África sempre fez parte desse universo simbólico igual aos outros povos. Está incluída no projeto de salvação, desde o início do cristianismo, e não desde a cristandade colonial com a qual fomos batizados com ferro, espada e fome.

Assim, observa-se que as novidades das nossas interpretações não se limitam tão-somente na afirmação de que a fé universalizante de Javé concretizada em Jesus inclui os marginalizados, oprimidos, castrados, representados na figura do etíope. De fato, o povo etíope é marginalizado só a partir da mentalidade racista ocidental. E talvez essa seja uma autocrítica à teologia da libertação que pesa o seu caráter eminentemente político, que pôs ênfase na situação de castrado e humilhado do etíope e não na sua procedência e status social, isto é, um país liderado por rainhas mães que tinham prestígio, poder e 
riquezas. Essa teologia, de certo modo, nos confinou à pobreza sem apenas perguntar pelas relações de poder econômico, político e social que nos limitaram ao fim do mundo em condições de extrema miséria, nem pelas implicações éticas que uma teologia paternalista e colonialista trouxera para nossos povos. Assim, perguntamo-nos até quando nossos olhos vão ter em conta a fome na Etiópia atual e na diáspora africana?

\section{CONSIDERAÇÕES FINAIS}

A violência perpetuada durante séculos pelo modelo europeu, por intermédio de meios violentos e não violentos de dominação, é diferente da construção de uma perspectiva teórica enraizada na experiência africana. É diferente, porque a busca de um centro africano não assume uma posição universalista, não pressupõe seus elementos como universais e aplicáveis a outras experiências humanas. É uma concepção pluralista que valoriza a visão do mundo de cada país. Elisa Larkin Nascimento, 1997, sintetiza muito bem nossa opção:

A tarefa acadêmica afrocêntrica consiste em estudar, articular e afirmar o que diferencia o ponto de vista africano, identificando ao mesmo tempo os postulados supostamente universais do eurocentrismo e desmascarando sua natureza específica (p. 221).

Por muito tempo a tendência dos pesquisadores do Antigo Testamento, ou das Escrituras Hebraicas, tem sido negar a participação e a influência das nações africanas na história de Israel. Especialmente na seção dedicada à geografia, é apresentada uma visão diferente da região sírio-palestina, as penínsulas arábica e mesopotâmica. O Egito é estudado apenas em poucas linhas, e no tópico referente ao Oriente Antigo, em vez de estudá-lo em uma seção especial dedicada à África. Da mesma forma, quando olhamos para um mapa da "terra da Bíblia", há uma tendência de desafricanização do Egito. Em outras palavras, "A maioria dos mapas apresenta apenas as áreas da região sírio-palestina e da região Leste e, se houver alguma representação da África, ela estará restrita ao Egito" (Randall BALEY, 1991, p. 166). 
Vale a pena reiterar que o que propomos aqui é romper com padrões e valores preestabelecidos pela tradição ocidental e questionar o acesso ao conhecimento eurocêntrico. Ou seja, um modelo epistemológico universal para todos os povos e culturas. Pois, nesse modelo filosófico, os chamados grupos periféricos não foram contemplados. Se essa ruptura ocorre, então é possível entender que, das periferias do mundo, o conhecimento também é construído. Neste sentido:

- O percurso histórico pelos movimentos de resistência das mulheres negras, em particular, possibilitou tirar do anonimato o papel ativo e constante das mulheres nas suas lutas e, sobretudo, na sua forma de construir conhecimento a partir de seus corpos, suas resistências, suas oralidades, suas presenças e ausências.

- Corroboramos a dificuldade que existe na reconstrução da história das mulheres negras, já que em muitos momentos foram invisibilizadas também dentro dos movimentos de resistência das negritudes, pelos seus colegas varões, os que aparecem na história como os grandes precursores das lutas abolicionistas, de consciência negra e críticas pós-colonialistas.

- Este estudo da rainha de Sabá e Candace nos permitiu reconsiderar a história dos povos africanos e árabes na história da interpretação, em sua localização conjunta: Península da Arábia e da África.

- Nos textos bíblicos, encontramos memórias culturais e religiosas não só do Israel monárquico mas, também, dos povos africanos e árabes que atuaram de maneira ininterrupta na história escrita que vai do século X a.C. e do século I-IV d.C. Assim, teríamos nas histórias de Zípora, a Sulamita, a rainha de Sabá e a rainha Candace uma forte confluência cultural e religiosa dos povos do horizonte africano na vida e cultura de Israel. Há uma participação ativa e constante do mundo africano dentro das experiências antropológicas do Israel bíblico e pós-bíblico. Quando somente se vê a história do povo de Israel e de Judá a partir de óticas ocidentais, deixa-se de considerar a África como uma das perspectivas culturais e religiosas para a compreensão da Palestina.

- Ao enfocar de maneira especial a experiência das mulheres para a análise, não pretendemos isolá-las, pois o ser humano é um ser re- 
lacional e histórico. E essa dimensão relacional envolve os corpos, já que eles experimentam as relacionalidades como constituição de seus cotidianos. Assumimos um compromisso com as mulheres e suas práticas, comumente não consideradas como dignas de importância para o processo emancipador dos grupos considerados excluídos, talvez porque essas vidas, esses corpos, foram interpretados só a partir de uma ótica androcêntrica. Por isso, nosso compromisso aponta também para o resgate da influência da sabedoria feminina afro-asiática na consolidação da fé mosaica.

Para terminar, estamos conscientes de que, em última instância, a interpretação final depende em grande medida da maneira como cada um de nós enfrenta o desafio de apropriar-se de novas fontes de conhecimento para além do paradigma eurocêntrico de conhecimento. Nosso convite inclui o desafio de não ser somente repetidores de doutrinas, teologias e ideologia aprendidas durante séculos ou porque estão em moda, e que muitas vezes não têm nada a ver com aquilo que nós somos. A hermenêutica bíblica feminista, além de ter um compromisso com a nossa história, é uma hermenêutica que causa rejeição pelo que nos obriga a sair da nossa mordomia. É um convite a gerar conhecimento além das margens da oficialidade, por isso, vai além dos cânones estabelecidos pela erudição acadêmica. Tomara possamos nos deixar interpelar e motivar para seguir o nosso rumo em busca de um futuro "negro e bonito" para os nossos descendentes.

\section{REFERÊNCIAS}

ARRAES, Jarid. Heroínas negras brasileiras em 15 cordéis, Polén Livros, 2017.

BARROSO, José María. Feminismo decolonial: una ruptura con la visión hegemónica eurocéntrica, racista y burguesa. Entrevista con Yuderkys Espinosa Miñoso. Iberoamérica Social: revista-red de estudios sociales (III), p. 22-33, 2014. Disponível em: http:// iberoamericasocial.com/feminismo-decolonial-una-ruptura-con-la-vision-hegemonica-eurocentrica-racista-y-burguesa/ Acesso em: 5 out. 2018.

BERNAL, Matin. Atenea Negra. Las raíces afroasiáticas de la civilización clásica. Barcelona: Crítica, 1993.

BOU, Luis César. África y la historia, en Pensar a contracorriente VI, Editorial de Ciencias Sociales, La Habana, 2009. 
BUDGE, Wallis. Teaching of Amen-Em-Apt, Son of Kanetht, Ed. Kessinger Publishing, 1924.

CALDEIRA, Cleusa. Hermenêutica Negra Feminista: um ensaio de interpretação de Cântico dos Cânticos 1.5-6. Rev. Estud. Fem., v. 21, n. 3. Florianópolis, set./dec. 2013. Disponível em: <http://www.scielo.br/scielo.php?script=sci_arttext\&pid=S0104-026X2013000300023> Acesso em: 8 out. 2018.

CASTRO-GÓMEZ, Santiago. Ciencias sociales, violencia epistémica y el problema de la 'invención del otro'. In: La colonialidad del saber: eurocentrismo y ciencias sociales. Perspectivas latinoamericanas, Edgardo Lander, editor, Editorial de Ciencias Sociales, La Habana, 2005.

CASTRO-GÓMEZ, Santiago, GROSFOGUEL, Ramón. El giro decolonial. Reflexiones para una diversidad epistémica más allá del capitalismo global. Bogotá: Siglo del Hombre editores; Universidad Central, Instituto de Estudios Contemporáneos y Pontificia Universidad Javeriana, Instituto Pensar, Bogotá, 2007.

DIOP, Cheik Anta. Contribuciones culturales de África y sus perspectivas. In: Kohn, Hans y Sokolsky, Wallace, "El Nacionalismo Africano en el siglo XX". Buenos Aires, Paidós, 1968.

DIOP, Cheik Anta. Origen de los antiguos egipcios. In: Historia Geral da África, tomo II, África Antiga. Gamal Mokhtar, editor, UNESCO, Brasília, 2010.

FANON, Franz. Los condenados de la tierra, Fondo de Cultura Económica, México, 1983. FONSECA, Melody; JERREMS, Ary. Pensamiento Decolonial: ¿una "nueva" apuesta en las relaciones internacionales. Relaciones Internacionales, n. 19, GERI - UAM, 2012.

GIBELLINI, Rosino. A Teologia do Século XX. Tradução de João Paixão Netto. São Paulo: Loyola,1998.

GRANT, Jackeline. White Women's Christ and Black Women's Jesus. Atlanta: Scholars Press, 1990.

JAMES, George M. Legado robado. La filosofía griega es filosofía egipcia robada. Falu Foundation, 2001.

KARNAL, Leonardo [et al.]. História dos Estados Unidos: das origens ao século XXI. São Paulo: Contexto, 2010.

KEBRA, Nagash. La Biblia secreta del Rastafari, Editorial Corona Borealis, 2010.

LARKIN, Elisa Nascimento. Sankofa: Resgatando a Cultura Afro-brasileira, em Abdias Nascimento (Org.). Thoth Escribas dos Deuses: Pensamento dos Povos Africanos e Afrodescendentes, Gabinete do senador Abdias Nascimento, Brasília, 1997.

MAYA, Adriana. La sensualidad y el cimarronaje femenino en el caribe, siglo XVII: Paula de Eguiluz y el arte del buen querer, Universidad de los Andes. Facultad de Humanidades y Ciencias Sociales, Bogotá, 2002. 
MENA-LÓPEZ, Maricel. Because of an Ethiopian Woman. Reflexions on Race, Gender, and Religion in the Biblical. In: Feminist Intercultural Theology - Latina Explorations For A Just World. Orbis Book, Maryknoll, p.145-165, 2007.

MENA-LÓPEZ, Maricel. Raíces afro-asiáticas en la Biblia. In: Revista de interpretación Bíblica Latinoamericana, RIBLA, 54, 2006.

MENA-LÓPEZ, Maricel. Raíces afro-asiáticas y la descolonización de la Biblia. Desafíos para la educación teológica latinoamericana. In: Re-encantos y re-encuentros: caminos y desafíos actuales de las teologías de la liberación. Daylíns Rufín Pardo; Luis Carlos Marrero (Org.). Centro de estudios-Consejo de Iglesias, La Habana, p. 74-84, 2017.

OJEDA PIZANO, Paola Rossana; CABALUZ, Ducasse; JORGE, Fabian. Colonialidad del poder y geopolítica del conocimiento. Reflexiones para repensar las pedagogías críticas. Revista electrónica diálogos educativos, n. 19, 2010.

PRADA, Hernán M. El nacimiento del Blues en el sur de los Estados Unidos, Universidad Javeriana (Proyecto para optar pelo título de Magister em Ciencias Sociales), 2015.

QUIJANO, Aníbal. Cuestiones y horizontes: de la dependencia histórico-estructural a la colonialidad/descolonialidad del poder. Buenos Aires: CLACSO, 2014.

RALSTON, Richard. A África e o novo mundo. In: Historia Geral da África VII. África sob dominação colonial 1880-1935, Albert Adu Boahen (Org.), p. 875-918, 2010. Ronald J, Williams. Egito e Israel. In: O legado do Egito, J. R. HARRIS (editor). Rio de Janeiro: Imago, p. 267-301, 1993.

SHOHAT, Ella. Notas sobre lo “postcolonial”. In: Estudios postcoloniales. Ensayos fundamentales, Creative Commons, Edición traficante de sueños, Madrid, 2008.

ULLENDORFF, Edward. Ethiopia and the Bible, Oxford University Press, 1988.

WALSH, Katerine. Interculturalidad crítica y educación intercultural. Disponível em: file:///D:/Downloads/interculturalidad\%20critica\%20y\%20educacion\%2ointercultural.pdf Acesso em: 5 jun. 2018.

WALTER, Monika. El Cimarrón en una cimarronada. Nuevos motivos para rechazar un texto y de la forma como este se nos impone. Revista de crítica latinoamericana, 36, 1992.

WEEMS, Renita J. Reading Her Way through the Struggle: African American Women and the Bible. In: Cain Hope FELDER, editor, Stony the Road we Trod. African American Biblical Interpretation. Minneapolis, Maryknoll, Orbis Books, 1991.

WILLIAMS, Dolores. Womanist Theology. Black Women's Voces. In: Weaving the Visions. New Patterns in Feminist Spirituality. J. Plaskow e C. Christ (Orgs.). San Francisco: Harper and Row, p. 179-186, 1989.

WILLIAMS, Dolores. Women's oppression and lifeline politics in black women's religious narratives. In: Journal of Feminist Studies in Religion, 1 (2): 59-71, 1985.

Submetido em: 6-11-2018

Aceito em: 26-11-2018 